\title{
Improving Performance of Heifer Buffalos Fed with Urea-treated Rice Straw Ensiled with Cassava Pulp Supplemented with Concentrates
}

\author{
Muhamad Bata $^{1} *$, Mas Yedi Sumaryadi ${ }^{1}$, Sri Rahayu $^{1}$ and Nova Marung ${ }^{2}$ \\ ${ }^{1}$ Faculty of Animal Science, Jenderal Soedirman University, Purwokerto, Indonesia \\ ${ }^{2}$ Student of Master Program, Faculty of Animal Science, Jenderal Soedirman University, Purwokerto, Indonesia \\ *Corresponding author email: muhamadbata@yahoo.com
}

\begin{abstract}
The objectives of this research were the optimalization of production and reproduction of buffalo heifers through improving feed quality based on rice straw. Twelve heifer buffaloes with body weight of $243-$ $350 \mathrm{~kg}$ were kept in individual cages and grouped to four. Each groups were randomized to receive three treatments of A, B and C according to Randomized Completely Block Design (RCBD). A was buffalo fed only rice straw. B was buffalo fed rice straw supplemented with concentrate with a dry matter ratio of 70:30. C was similar to $B$ but the rice straw was ammoniated using urea of $4 \%$ ensiled with $8 \%$ of cassava pulp. In-Vitro test was conducted to measure rumen fermentation product. The results showed the highest of DM and OM digestibility was achieved at $C$ treatment, while the lowest was found at A treatment. Rumen fermentation produsts and its efficiency were the highest in $C$ treatment. In-vivo result showed that ADG of $C$ was higher than that of $B$ and $A$. Reproductive performance characterized by frequency oestrus for 123 days were an average of 2.5, 2.8 and 4.5 times for A, B and C, respectively. The highest blood metabolite of glucose, urea and erytrocyt was found at $C$ but the leucocyt was lowest compared to $A$ and $B$. Urea treated rice straw ensiled with cassava pulp and supplemented with concentrate can improve production and reproduction performance of heifer buffaloes.
\end{abstract}

Keywords: digestibility, reproduction, metabolite, rumen, ammoniation

\begin{abstract}
Abstrak. Salah satu faktor yang menghambat perkembangan kerbau di Indonesia adalah ketersediaan pakan yang berkualitas. Tujuan penelitian ini adalah optimalisasi produksi dan reproduksi kerbau melalui peningkatan kualitas pakan berbasis jerami padi. Dua belas ekor kerbau dengan berat badan $243-350 \mathrm{~kg}$ dipelihara di kandang individu dan dikelompokkan menjadi empat kelompok. Setiap kelompok diacak untuk menerima tiga perlakuan A, B dan C sesuai dengan Rancangan Acak Kelompok. A adalah kerbau hanya diberi jerami padi. B adalah kerbau yang diberi pakan jerami padi yang disuplementasi dengan konsentrat dengan rasio bahan kering 70:30. $C$ adalah sama dengan perlakuan $B$, akan tetapi jerami padi diamoniasi menggunakan urea $4 \%$ yang disilase dengan onggok $8 \%$ dari berat jerami padi. Uji In-Vitro dilakukan untuk mengukur produk fermentasi rumen. Hasil penelitian menunjukkan kecernaan DM dan OM tertinggi dicapai pada perlakuan C, sedangkan yang terendah ditemukan pada perlakuan A. Produk fermentasi rumen dan efisiensinya paling tinggi dalam perlakuan C. Hasil uji in-vivo menunjukkan bahwa PBBH C lebih tinggi dibandingkan dengan $\mathrm{B}$ dan A. Kinerja reproduksi yang ditandai dengan frekuensi oestrus selama 123 hari adalah rata-rata 2,5; 2,8; dan 4,5 kali masing-masing untuk $A, B$ dan $C$. Metabolit darah tertinggi dari glukosa dan eritrosit ditemukan pada $C$ dibandingkan dengan $A$ dan $B$, akan tetapi leukosit adalah yang terendah. Amoniasi Jerami padi dengan urea yang disilase dengan onggok yang disuplementasi dengan konsentrat dapat meningkatkan kinerja produksi dan reproduksi kerbau.
\end{abstract}

Kata kunci: kecernaan, reproduksi, metabolit, rumen, amoniasi

\section{Introduction}

One factor that inhibits the development of buffalo in Indonesia is the availability of feed quality. Low quality feeding and low nutrients availability, either improper or inadequate, provides a low energy status which will decrease production and reproductive performance (Sahoo et al., 2004 and Wynn et al., 2009). In addition, buffalo has intrinsic properties, such as poor estrus expression, oestrus symptoms that are not as clear as in cows, changes in the external genitals, vulva discharge and sexual behavior (Warriac et al., 2015). However, high reproduction efficiency of buffalos could be achieved through nutrient 
supplementation (Dinesh et al., 2016) and better feeding management (Wynn et al., 2009 and Diwakar et al., 2017).

The main diet of buffalo in Indonesia is rice straw which is one of the agricultural byproducts that are abundantly available in many tropical countries (Nguyen et al., 2017). It does not provide enough nutrients to the ruminants to achieve high production levels because the low nutritive value indicates a high level of lignification and silicification. In addition, the slow and limited ruminal degradation of the carbohydrates and the low content of nitrogen are the main deficiencies of rice straw, affecting its value as feed for ruminants (Kholif et al. 2014 and Liu et al. 2015) and low ruminal ammonia nitrogen (NH3-N) that often limits microbial growth and ruminal fermentation (Lizarazo et al. 2014). Therefore, it requires treatments to improve its quality.

Chemical treatments, like urea, currently seem become more practical for on farm use. However, release of NH3-N from urea treated crop residues making whole process unefficient and caused environmental pollution (Khan et al., 2004). Most of the NH3-N in urea-treated crop residues is held as water-soluble that released rapidly in rumen and results in high $\mathrm{NH} 3$ production in rumen and ultimately increases blood urea. The increased ruminal $\mathrm{NH} 3$ and blood urea would decrease dry matter intake (DMI) and reduce conception rate in buffaloes, similar to those observed in dairy cattle (Dhali et al., 2006). Using diffrent sources of fermentable carbohydrates have been reported to retain this escaped $\mathrm{N}$ in ureatreated wheat straw (Khan et al., 2004 and Khan et al., 2005). Nisa et al. (2004) reported that urea-treated wheat straw ensiled with corn steep liquor (CSL) resulted in better $\mathrm{N}$ fixation. Urea treated corn cob ensiled with enzose or acidified molasses resulted increasing digestibility and $\mathrm{N}$ utilization than those ensiled without any additive, with non-acidified molasses and acidified water in buffaloes (Khan et al., 2006). Ammoniation of rice straw using urea ensiled with molasses can improve quality of ammoniation through enhancing of dry matter and organic matter digestibility in-vitro (Bata, 2008). Syapura et al. (2013) reported that concentrate supplementation to rice straw ammoniation with urea ensiled with cassava pulp can increase rumen fermentation product of buffalo in-vitro.

Onggok (cassava pulp) is a byproduct of cassava processing for tapioca production, which contains high fermentable carbohydrates like corn step liquor or enzoze. Therefore, it might be used for ensiling rice straw ammoniated with urea fed to heifer buffalo. This study aims to determine the effect of rice straw (urea-treated and non-treated) ensiled with cassava pulp supplemented with concentrates on performance of heifer buffalo.

\section{Materials and Methods}

\section{In-Vitro Test \\ Diets Preparation}

A total of $10 \mathrm{~kg}$ of dry rice straw (air-dried) was divided into two parts, $5 \mathrm{~kg}$ each. Five $\mathrm{kg}$ was amoniated using 4\% urea supplemented with $8 \%$ of cassava by-products (onggok) based on the weight of rice straw were dissolved in 10 liters of water and then sprinkled onto rice straw that was pre-cut $3-5 \mathrm{~cm}$. The mixture was put in a plastic bag, compacted and closed tightly and left for up to 21 days. After 21 days, the bag was opened and aired. Sampling of ammonia and non-ammonia rice straw was carried out as much as $10 \%$ of the total weight. The sample was dried in an oven at $60^{\circ} \mathrm{C}$ for 24 hours and then blended through a $5 \mathrm{~mm}$ screen filter. They were mixed to concentrates with dry matter rasio according to the treatment as listed in Table 2. The nutrient content of rice straw, ammoniated rice straw and concentrates was listed in Table 1. 
Table 1. Nutrients content of rice straw, rice straw ammoniated and concentrate ( $100 \%$ of DM)

\begin{tabular}{lccc}
\hline Nutrients (\%) & Rice straw & Rice straw ammoniated & Concentrate \\
\hline Crude protein & 3.45 & 6.66 & 14.05 \\
Ethyl extract & 1.20 & 1.21 & 2.68 \\
Crude fiber & 33.02 & 35.19 & 8.20 \\
Ash & 25.06 & 25.18 & 2.69 \\
NFE & 37.27 & 31.76 & 48.19 \\
NDF & 71.79 & 53.28 & 46.31 \\
ADF & 27.58 & 25.67 & 20.85 \\
\hline
\end{tabular}

Tabel 2. Dry Matter (DM) Compostition and Nutrient Contents of Treatment Diets

\begin{tabular}{lccc}
\hline Feedstuff & \multicolumn{3}{c}{ DM ratio of Treatments Diet (\%) } \\
\cline { 2 - 4 } & $\mathrm{A}$ & $\mathrm{B}$ & $\mathrm{C}$ \\
\hline Rice Straw & 100 & 70 & 70 \\
Rice straw ammoniated & & 30 & 30 \\
Concentrate & & $100 \%$ of DM & \\
\hline Nutrient contents & 3.45 & 6.63 & 8.87 \\
\hline Crude Protein & 1.20 & 1.64 & 1.65 \\
Etyl Extract & 33.02 & 25.57 & 27.09 \\
Crude Fiber & 25.06 & 18.35 & 18.43 \\
Ash & 37.27 & 40.55 & 36.69 \\
NFE & 71.79 & 64.15 & 51.19 \\
NDF & 27.58 & 25.56 & 24.22 \\
ADF & &
\end{tabular}

There were three treatments of $A, B$ and $C$ being tested using a completely randomized design. A treatment as a control only used rice straw. B treatment was rice straw plus concentrate with a dry matter ratio of $70: 30$, while treatment $C$ was the same ratio as $B$, but the rice straw was replaced with ammoniated rice straw using urea ensiled with cassava by product at a dose of 4 and $8 \% \mathrm{w} / \mathrm{w}$ air-dried rice straw.

The in-vitro test procedure was carried out according to Tilley and Terry (1963) procedure. McDougal solution with $\mathrm{pH} 6.8$ was heated to $39^{\circ} \mathrm{C}$ and mixed with rumen fluid. A total of 36 $\mathrm{ml}$ of the mixture was poured into Erlenmeyer which had been filled with 2 grams of feed tested according to treatments. The mixture was flowed with $\mathrm{CO}_{2}$ and then covered with a butyl rubber stopper. Erlenmeyer containing the tested feed, McDougal and rumen fluid were given $\mathrm{CO}_{2}$ and incubated in a shaker water bath at $39^{\circ} \mathrm{C}$ for 4 hours. After that, the lid of the tube was opened and transferred to the centrifuge tube. The medium was centrifuged at a speed of $6000 \mathrm{rpm}$ for 30 minutes to separate the supernatant and residue deposits. The supernatant was accommodated and the residue was dried in an oven at $106^{\circ} \mathrm{C}$ for 8 hours. The variables measured were total and partial VFA production, N-NH3 and rumen microbial protein synthesis (MPS).

\section{Chemical Analysis}

A total of $2 \mathrm{ml}$ of the supernatant collected was centrifuged at $13000 \mathrm{rpm}$ for 1 minute. The supernatant $(64 \mu \mathrm{L})$ was mixed with $736 \mu \mathrm{L}$ water, $30 \mu \mathrm{L}$ internal standard (2-ethylbutyric acid) and $100 \mu \mathrm{L}$ formic acid and again centrifuged at a speed of 13,000 rpm for 1 minute. The supernatant samples were stored at $8^{0} \mathrm{C}$ for partial volatile fatty acid (VFA) analysts using Gas Chromatography according to the procedure performed by (Joch et al. 2016). In summary as follows, $1 \mu$ was injected on the injector with an injector temperature of $200^{\circ} \mathrm{C}$ and an internal pressure of $50 \mathrm{kPa}$. The 
program temperature was $75^{\circ} \mathrm{C}$ at the time of injection, increasing $5^{\circ} \mathrm{C} / \mathrm{min}$ to $80^{\circ} \mathrm{C}$ (kept for 1 minute), and then increasing $6^{\circ} \mathrm{C} / \mathrm{min}$ to $128^{\circ} \mathrm{C}$ (kept for 10 minutes). The detector temperature was $200^{\circ} \mathrm{C}$.

The supernatant was also used to determine the levels of N-NH3 using Micro diffuse Conway (Davis and Smith, 1958) and VFA total with steam distillation techniques (Krooman et al., 1967). Microbial protein synthesis was also measured using the centrifuge stepwise modification method of Makkar et al. (1982).

\section{In-Vivo Test}

\section{Animal Management}

A total of 12 heifer buffaloes of 2.5 - 3 years with an initial weight of $243-350 \mathrm{~kg}$ (average of $288.5 \pm 11.28 \mathrm{~kg}$ ) were kept in individual cages of $2 \times 3 \mathrm{~m}$. They were grouped to 4 , namely I, II, III and IV for $247.33 \pm 7.50,277.33 \pm 6.93,303 \pm$ 3.61 and $326.67 \pm 21.73$ (IV), respectively. The study was conducted an experimental method designed according to the Randomized Complete Block Design (RCBD) with the initial weight of buffalo as groups. Each group randomly received treatments $A, B$ and $C$. A was buffalo fed only with rice straw (control). B was buffalo received diets of rice straw supplemented with concentrate with a ratio DM of $80: 30 \%$ and C treatment was the same as $B$, but the rice straw was amoniated using urea ensiled with cassava pulp (Bata, 2008). The concentrate consisted of bran polar, rice bran, cassava byproduct, mineral mix, salt, limestone and urea in DM ratio of $22 ; 21 ; 32 ; 23 ; 0.5 ; 1.0$; 0.5 and $1 \%$, respectively. DM intake of each buffalo was calculated at $3.2 \%$ of the body weight.

Rice straw was fed four times at 07.00, 09.00, 14.00 and 17.00, while concentrates for buffaloes group $B$ and $C$ were fed 2 times at 07.00 and 14.00 . There were two stages of this research. The first was digestion trial conducted according to the total collection method (Krause et al., 1998), and the second stage was feeding trial for 123 days. Variables measured were digestibility coefficient of dry matter (DMD), organic matter (OMD) and protein (CPD), blood metabolites (glucose, protein and urea) and blood hematology $(\mathrm{Hb}$, red blood cells and white blood cells), daily weight gain (ADG), reproductive performance (oestrus and frequency of oestrus).

\section{Sampling and Chemical Analysis}

Sampling of feeding, remaining feeds (rice straw and concentrate) and feces were carried out randomly every day in the morning during the collection period ( 5 days). They were dried at $60^{\circ} \mathrm{C}$ for three days. The collected sample were composited on the days of collection. Chemical analysis for water content, ash, crude protein, NDF and ADF in samples of feed, remaining feed and feces were carried out according to AOAC procedures (2019). Blood samples were taken through jugular vein after feeding trial and carried out 4 times: before morning feeding, 2 hours, 4 hours and 8 hours after feeding. The blood serum was kept frozen for analysis. After thawing, $N$ urea was measured using an autoanalyzer (Beckman SYNCHRON CX ${ }^{\circledR}$ SYSTEMS, Beckman Instruments, Inc., Brea, $\mathrm{CA}$ ) and blood $\mathrm{N}$ urea reagents (BUN reagents). Glucose concentration in plasma was analyzed using a commercial spectrophotometer kit (Sigma Tech, Bull. No.315; Sigma Chemical, St. Louis, MO).

\section{Statical Analysis}

All obtained data were subjected to the general linear model procedures of the Statistical Analysis System Institute (SAS, 1998) according to the Randomized Block Design (CBD) for in-vivo and Completely Random Design (CRD) for in-vitro research. Multiple comparisons among treatment means were performed using the Least Significant Different (LSD) (Steel and Torrie, 1980). 


\section{Results and Discussion}

\section{Nutrient digestion and rumen fermentation products In-Vitro}

The average production of VFA, N-NH3, MPS and ratio of C2 / C3 in various treatment diets are listed in Table 3. Analysis of variance showed that improving the quality of rice straw through supplementation with concentrates and ammoniated rice straw ensiled with cassava pulp had a significant effect $(P<0.05)$ on rumen fermentation products (VFA) , N-NH3, MPS and C2 / C3). The highest production of VFA, N-NH3 and MPS $(\mathrm{P}<0.05)$ was achieved in the $\operatorname{diet} C$ followed by $B$ and $A$. However, C2 / $C 3$ ratio at $C$ diet was lower $(P<0.05)$ compared to the diet containing only rice straw $(A)$ and rice straw supplemented with concentrate (B).

The low fermentation product in treatment A was in line with Zhang et al. (2018). Low rice straw digestion in ruminants is caused by low protein content, high lignin and silica content and phenol, carbohydrate degradation in low rumen (Kholif et al. 2014 and Liu et al. 2015). There are two main components of rice straw, i.e. cell contents and cell walls. Livestock easily digest cell contents, but cell walls are very difficult to digest. Wyman et al. (2005) reported that the straw cell wall is composed of $5.5 \%$ lignin, $40 \%$ cellulose and $18 \%$ hemicellulose. Lignin is the main component which is an amorpous polymer made from different penol compounds and cannot be digested by rumen microorganisms (Oladosu et al. 2016). In addition, rice straw has a low fermentable protein and carbohydrate content, so supplementation with a high protein and fermentable carbohydrate in the concentrate in B treatment was able to supply more nutrients and energy that is digested in making it easier for rumen microbes to digest it. As a result, the fermentation products, such as VFA, N-NH3 and MPS increased in treatment $B$ compared to $A$.

High levels of lignification and silification make rice straw very difficult to digest because lignin inhibits the rate and degree of degradation and silica inhibits colonization of rumen microorganisms (Van Soest, 2006). Effective effort to overcome this problem is by alkaline treatment because alkaline agents can be absorbed into the cell wall and can chemically damage / stretch the ester bonds between lignin with cellulose and hemicellulose (Sarnklong et al . 2010). Sarwar et al. (2009) said that ammoniation can break the linkage between hemicellulose and lignin and make the hemicellulose fraction partially soluble to NDF solutions. The soluble hemicellulose would be highly digestible by ruminal micro-organisms. Therefore, urea treated rice straw ensiled with cassava pulp in $\mathrm{C}$ treatment produced higher fermentation products compared to B. In addition, energy efficiency in the rumen was better as indicated by the lower $\mathrm{C} 2$ / C3 ratio in C compared to $\mathrm{B}$, although both were supplemented with concentrate.

Table 3. Volatile fatty acid (VFA), nitrogen ammonia $\left(\mathrm{N}-\mathrm{NH}_{3}\right)$, microbial protein synthesis (MPS) and acetate propionate ratio (C2/C3) of different diets.

\begin{tabular}{llll}
\hline Variables & \multicolumn{3}{c}{ Diets } \\
\cline { 2 - 4 } & \multicolumn{1}{c}{$A$} & \multicolumn{1}{c}{ B } & \multicolumn{1}{c}{$\mathrm{C}$} \\
\hline VFA $(\mathrm{mM})$ & $98.90^{\mathrm{a}} \pm 3.80$ & $112.50^{\mathrm{b}} \pm 3.59$ & $125.39^{\mathrm{c}} \pm 2.44$ \\
$\mathrm{~N}-\mathrm{NH}_{3}(\mathrm{mM})$ & $8.86^{\mathrm{a}} \pm 0.58$ & $9.69^{\mathrm{b}} \pm 0.41$ & $11.98^{\mathrm{c}} \pm 0.82$ \\
$\mathrm{MPS}(\mathrm{mg} / 20 \mathrm{ml})$ & $24.53^{\mathrm{a}} \pm 0.80$ & $26.43^{\mathrm{b}} \pm 0.73$ & $32.33^{\mathrm{c}} \pm 1.18$ \\
$\mathrm{C} 2 / \mathrm{C} 3$ & $2.69^{\mathrm{a}} \pm 0.12$ & $2.41^{\mathrm{a}} \pm 0.19$ & $2.25^{\mathrm{b}} \pm 0.17$ \\
\hline
\end{tabular}

Mean within rows with different superscripts differ significantly $(\mathrm{P}<0.05)$ 
Nutrient Digestion and Performance (Growth and Reproduction)

Analysis of variance showed that increasing the quality of rice straw both supplementation with concentrate and ammoniation supplemented with concentrate as much as $30 \%$ of dry matter had a very significant effect ( $p<0.01$ ) on DMD, OMD and CPD. The highest DMD, OMD and CPD were achieved $(P<0.05)$ in treatment $C$ compared to treatments $B$ and $A$ (Table 4). These results were in agreement with those found by (McGuire et al. 2013, Sweeny et al. 2014 and Wanapat et al. 2016). These results were consistent with the in vitro conditions previously discussed.

The low DMD, OMD and CPD in the buffalo group fed only rice straw was because rice straw has several limitation including low nitrogen $(\mathrm{N})$ or protein content and high crude fiber, so digestibility and palatability are low (Kholif et al., 2014 and Liu et al., 2015). In addition, nitrogen ammonia (N-NH3) produced is also low which inhibits microbial growth and rumen fermentation (Lizarazo et al., 2014). Nitrogen deficiency will reduce the population of microorganisms, making it difficult to digest the nutrients contained in rice straw. Rumen microbial growth is highly dependent on the availability of $\mathrm{N}$ in the form of peptides, amino acids and NH3 (Russel et al., 1992). The amount of fermentable carbohydrates is also low that are the initial source of energy for rumen microorganisms. Maeng et al. (1997) reported that the amount of small fermentable carbohydrates will result in low rumen microbial protein (MP) production efficiency.
Supplementation of concentrate in rice straw will increase $D M D, O M D$ and $C P D$ in $B$ treatment because the concentrate contains a lot of fermentable carbohydrates, so that it can stimulate the activity of rumen microorganisms to develop and move so as to digest the nutrients present in the rice straw. The increase in $\mathrm{DMD}, \mathrm{OMD}$ and $\mathrm{CPD}$ achieved in $\mathrm{B}$ treatment was still lower compared to treatment $\mathrm{C}$. Rice straw contains ligno-cellulose and lignohemicellulose bonds which are moderately high to inhibit rumen microbial access to induce cellulose and hemi cellulose, as well as other cell components. Rice straw as animal feed has limitations, such as low protein content and digestibility due to high lignocellulose content (Khan et al. 2006).

The characteristics of rice straw is the high undigested fiber due to high levels of cellulose lignification, hence decreasing digestion (Nisa et al., 2004). In addition, the nitrogen content is also low (Orden et al., 2000). Ammoniation is one way to overcome these problems. The ammonia produced during the ammonia process can stretch lignocellulose and increase the $\mathrm{N}$ content. Therefore, supplementation of ammoniated rice straw with concentrate can optimize the activity of rumen organisms because besides providing access to digest cellullose and hemicellulose as well as other cell contents, microorganisms also receive a sufficient supply of nitrogen and fermentable carbohydrates to produce the highest digestibility. As a result, $\mathrm{C}$ treatment produced high rumen-fermented products (in vitro) and DMD, OMD and CPD digestibility (in vivo).

Table 4. Digestion koeficien of dry matter (DMD), organic matter (OMD) and crude protein (CPD) of heifers buffalo fed diets with different treatments

\begin{tabular}{lccc}
\hline \multirow{2}{*}{ Variables } & \multicolumn{3}{c}{ Diets } \\
\cline { 2 - 4 } & $\mathrm{A}$ & $\mathrm{B}$ & $\mathrm{C}$ \\
\hline DMD (\%) & $38.22 \pm 2.14^{\mathrm{a}}$ & $54.07 \pm 09.32^{\mathrm{b}}$ & $57.87 \pm 6.24^{\mathrm{c}}$ \\
OMD (\%) & $49.46 \pm 4.43^{\mathrm{a}}$ & $79.43 \pm 4.21^{\mathrm{b}}$ & $85.05 \pm 3.20^{\mathrm{c}}$ \\
CPD (\%) & $32.59 \pm 0.08^{\mathrm{a}}$ & $55.49 \pm 10.34^{\mathrm{b}}$ & $62.01 \pm 6.53^{\mathrm{c}}$ \\
\hline
\end{tabular}

Mean within rows with different superscripts differ significantly $(P<0.05)$ 


\section{Production Performance (Growth and Reproduction)}

The ADG of buffalos in treatment $A, B$ and $C$ were $0.05 \pm 0.12 \mathrm{~kg}, 0.23 \pm 0.05 \mathrm{~kg}$ and $0.53 \pm$ $0.09 \mathrm{~kg}$, respectively. Analysis of variance showed that the treatment had a significant effect $(P<0.01)$ on ADG. Buffaloes fed only rice straw (group $A)$ had a lower $(P<0.01)$ ADG compared to those fed on rice straw supplemented with concentrate ( B) and ammoniated straw supplemented with concentrate (C).

The low ADG of buffalos in group $A$ was due to the low quality of rice straw. These results were consistent with the digestibility of nutrients and fermented products and their low efficiency (C2 / C3) as discussed earlier. The low protein content and high polysaccharide structure had a drastic effect on decreasing the consumption of dry matter and digestion, which in turn affects livestock performance (Safari et al., 2012). Supplementation of rice straw with concentrate can overcome these deficiencies so as to improve digestibility and ultimately had a positive effect on buffalo performance in group B. However, the increase in ADG in buffalo group $B$ was still lower than that in group $C$. These results were consistent with the increased digestibility of nutrients and fermented products and energy efficiency resulting from treatment $C$ treatment is higher than B which was discussed earlier. These results are consistent with those reported by Gunun et al. (2013) supplementation of ammoniated rice straw supplemented with concentrate can increase consumption, digestibility, rumen fermentation and efficiency of microbial protein synthesis in crossbreed dairy cows. In addition, the high leucocyte in buffalo group $A$ is also one of the causes of the low ADG because high leucocyte is an indicator that the buffalo is experiencing stress.

During 123 days group A buffalo only showed oestrus sign 3 out of four $(75 \%)$, whereas group $B$ and $C$ buffalo were all oestrus sign (100\%). The frequency of oestrus ranged from 0 to 4 times with a mean of 2.5 times for group A, while group B was 2-3 times with an average of 2.5 times and group $C$ of 3-5 with a mean of 4.25 times. The low reproductive performance in buffalo group $A$ is due to the very low nutritional status as indicated by the low fermentation products and their efficiency, nutrient digestibility, erytrocytes and blood glucose and high leucocytes compared to groups B and C as previously discussed. Abd ElRazek and Allam (2019) reported that biochemical parameters and hematological picture in case anestrus in buffalo-cows are characterized by significant decrease in red blood cells, $\mathrm{Hb}$, pocket cell volume, total protein, albumin, globulin, glucose, FSH and progesterone while there was an increase in TLC, neutrophil, eosinophil and lymphocyte. The average blood glucose level of buffalo group A, B and C after two hours of continuous feeding was $49.72 \pm 9.45 ; 191.84 \pm 9.26$ and $199.81 \pm 19.75$. Glucose is a source of energy that is very closely related to the reproduction of ruminants. Increased glucose in buffalo group $B$ and $C$ was due to the feed of two groups containing concentrate as a source of propionate which is the basic ingredient for glucose formation. Greater values of blood glucose on supplementation of high energy diet were reported in buffaloes by Khan et al. (2016). Scaramuzzi et al. (2006) said that increased blood glucose levels in sheep directly influenced the increased use of glucose by the ovary which suppresses the secretion of the hormone oestradiol. This decrease in hormones will signal to the hypothalamus to secrete the FSH hormone which stimulates follicle cell formation and ovulation.

One buffalo in group A did not experience oestrus during the study (123 days). This is because the buffalo has decreased body weight which is one of the consequences of metabolism due to the status of metabolism "negative energy balance". Its effects on 
reproduction, according to Scaramuzzi et al. (2006) are inhibition of GnRH secretion by the hypothalamus, low FSH concentration, inhibition of follicle formation, low estradiol, no ovulation and oestrus and prolonged puberty. This shows that buffalo with good nutritional condition will oestrus more regularly than buffalo that lacks nutrients. Group $\mathrm{C}$ has a better growth rate $(0.53 \mathrm{~kg} /$ day) so that body weight to reach adult sex and adult body is better, due to buffalo further oestrus faster than group A and B. Abdel-Latif et al. (2016) reported that supplementation of propylene glycol and calcium propionate as glycogenic sources to primiparous buffalo cows during the late gestation and early lactation period had a positive impact on live body weights and reproductive parameters as first estrus postpartum, days open and number of service per conception and blood metabolites as NEFA, BUN and glucose concentration.

Buffalo fed diet $C$ had very clear and longer symptoms of oestrus compared to buffalo $A$. In addition, the time of oestrus in this buffalo group in the afternoon, not at night and the cycle is more regular. These results were different from studies of estrous and endocrinological behavior in buffaloes conducted by Roy and Prakash (2009) and Singh et al. (2000) showing that it is common for large variations in reproductive endocrine activity with no external signs of estrus clear (silent heat). Warriach et al. (2015) states that buffalo tends to show signs of lust at night, making it difficult for farmers to detect it. High incidence of silent or anestrus or anovulation may be attributed the low circulation of $17-\beta$ oestradiol concentrations (Phogat et al., 2016). However, high fertility can be achieved through good feeding and management (Qureshi et al. 2007), so improving feed quality in this study can overcome the deficiency or constraints of buffalo (buffalo group C). The Estrus was regular with clear signs (Figure 1), lasted for quite a long time and occurred in the afternoon. The signs of estrus buffaloes include swelling of the vulva, warm vulva when being held, a raised tail and remains immobile (Figure 1). Conversely, non-oestrus buffalo will close its tail tightly when held by the vulva and always refuses.

High temperatures in the tropics such as Indonesia are one of the causes of decreased sexual activity during the day and a short period of estrus and silent oestrus events (Kumar et al., 2018). Buffalos received only rice straw like $A$ treatment will produce high acetate $(C 2)$ in the rumen so that the $\mathrm{C} 2$ / C3 ratio was low. Metabolism of acetate (related to high fibre diet) produces more endogenous heat than propionate (related to highconcentrate diet. Therefore, the increased dietary fibre intake may increase heat load and then heat stress (Conte et al., 2018). This heat must be removed and it is difficult for buffalo living in the tropics, so the buffalo receiving treatment $A$ experiences stress which is characterized by high leucocyte in its blood. To overcome this problem, feed containing high fermentable carbohydrates can be used to stimulate energy consumption, but positive effects must be balanced with the potential for acidosis (West et al. 2003). Diets rich in starch and poor in fibre reduced heat stress in lactating dairy cows because the metabolised energy from high concentrate diets is used with greater efficiency than the metabolised energy from high forage diets (Conte et al., 2018). Therefore, group B and $C$ buffalo have better reproduction due to improved quality of rice straw feed through amoniation and supplementation with concentrates so as to produce low acetate and high propionate or C2 / C3 ratio to be lower than those produced from buffalo group $A$. 


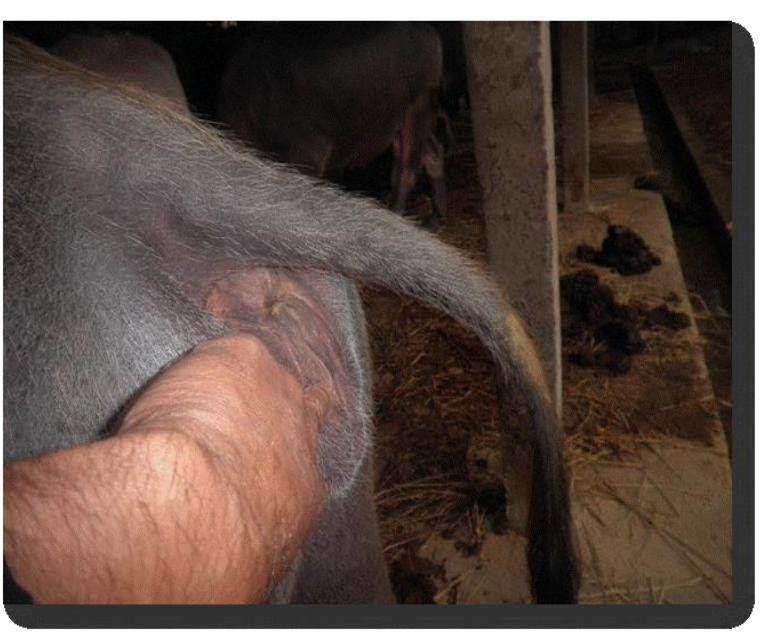

Figure 1. Oestrus sign of one buffalo fed diet C

\section{Blood Metabolite}

The average metabolites of buffalo blood fed different diets were listed in Table 5 . Analysis of variance showed that the treatment had a significant effect $(P<0.05)$ on glucose levels two hours after feeding, but had no significant effect ( $P>0.05$ ) against fasting glucose levels and 4 hours after eating. The increased in glucose levels in buffaloes of $B$ and $C$ treaments were because they were fed concentrates containing starch (Table 2). Huntington (1996) reported that the use of starch in ruminants is closely related to glucose requirements. As much as $44 \%$ of glucose supply comes from organic acids such as propionate and lactate from starch fermentation and $23 \%$ from other carbon sources such as amino acids. Feeds containing concentrates produced a fermentation pattern that increases the proportion of propionate compared to feed containing only forages. Therefore, buffalo fed diet B and $C$ had high glucose levels compared to buffalo that received diet $A$.

Buffaloes with fasting conditions did not get a feed supply, so the glucose levels were relatively similar across groups A, B and C. There was a drastic increase in blood glucose levels in buffalo groups B and C after two hours of feeding. This was because the two buffalo groups were fed concentrates that contained fermentable carbohydrates (cassava pulp, polar bran and ricebran). Whereas in group A only experienced a slight increase because the diet fed was only rice straw which contained carbohydrates that were difficult to digest.

Glucose levels in A treatment increased dramatically after 4 hours of feeding and at the same time blood glucose levels in B and C treatments began to decrease. This increase was in line with the increased activity of the rumen microorganism digestion process towards rice straw fed because rice straw is a material that is slow to digest. Whereas the decreased in $B$ and $C$ treatment was due to ruminant blood levels regulated by the hormones insulin and glucagon. High glucose levels will stimulate insulin secretion and insulin function is to increase cell permeability so that it can absorb glucose.

Glucose in ruminants has an important role such as the main source of energy in nerve tissue, especially in the brain and red blood cells. Therefore, buffalo fed diet B and C containing concentrate as carbohydrates fermentable sources had a high red blood cell (erythrocytes) compared to buffalo received $\operatorname{diet} A$ (Table 5). This was different from leucocytes whose levels are low $(P<0,05)$ in buffaloes fed $B$ and $C$ compared to buffaloes that are fed $A$. This is because buffalo fed rice straw just experience stress. In vitro data indicated that diet A having high C2 / C3 ratio or high producing of $\mathrm{C} 2$ and $\mathrm{C} 2$ metabolism produced high heat. This heat was difficult for buffalo to get rid of because of the high temperature and humidity around it. This situation created stress and one of the symptoms of stress is high leucocytes in the blood. 
Table 5. Blood metabolite of glukosa, urea, protein, leucocyte dan Eritrocyt levels at the fasting, 2 and 4 hours after feeding at different treatments

\begin{tabular}{|c|c|c|c|c|}
\hline \multirow{2}{*}{ Trearments } & \multirow{2}{*}{ Variable } & \multirow{2}{*}{ Fasting } & \multicolumn{2}{|c|}{ After feeding (Hours) } \\
\hline & & & 2 & 4 \\
\hline \multirow[t]{4}{*}{$A$} & Glucosa (mg/ml) & $27.37 \pm 7.87^{a}$ & $49.72 \pm 9.45^{\mathrm{a}}$ & $122.06 \pm 7.80^{\mathrm{a}}$ \\
\hline & Urea $(\mathrm{mg} / \mathrm{ml}$ & $25,17 \pm 2,74^{a}$ & $23,94 \pm 2,76^{a}$ & $4,28 \pm 1,39^{a}$ \\
\hline & Erytrocyt $\left(10^{6} / \mathrm{mm}^{3}\right)$ & $2,94 \pm 0,63^{a}$ & $7,65 \pm 0,96^{a}$ & $8,66 \pm 0,83^{a}$ \\
\hline & Leucocyt $\left(10^{3} / \mathrm{mm}^{3}\right.$ & $11,40 \pm 1,23^{\mathrm{a}}$ & $14,33 \pm 1,59^{a}$ & $14,05 \pm 1,51^{\mathrm{a}}$ \\
\hline \multirow[t]{4}{*}{ B } & Glucosa $(\mathrm{mg} / \mathrm{ml})$ & $24.48 \pm 4.48^{\mathrm{a}}$ & $191.84 \pm 9.26^{b}$ & $125.06 \pm 3.21^{\mathrm{a}}$ \\
\hline & Urea $(\mathrm{mg} / \mathrm{ml}$ & $26,57 \pm 1,47^{b}$ & $26,15 \pm 5,89^{b}$ & $4,87 \pm 2,31^{a}$ \\
\hline & Eryttrocyte $\left(10^{6} / \mathrm{mm}\right)$ & $3,58 \pm 0,73^{b}$ & $9,28 \pm 1,12^{b}$ & $9,28 \pm 1,12^{b}$ \\
\hline & Leucocyte $\left(10^{3} / \mathrm{mm}^{3}\right.$ & $12,18 \pm 1,73^{\mathrm{a}}$ & $10,74 \pm 1,38^{b}$ & $11,91 \pm 2,62^{b}$ \\
\hline \multirow[t]{4}{*}{ C } & Glukosa (mg/ml) & $27.69 \pm 12.22^{\mathrm{a}}$ & $199.81 \pm 19.75^{c}$ & $138.39 \pm 4.34^{\mathrm{a}}$ \\
\hline & Urea $(\mathrm{mg} / \mathrm{ml}$ & $30,44 \pm 1,78^{\mathrm{a}}$ & $34,69 \pm 4,77^{c}$ & $19,50 \pm 8,69^{b}$ \\
\hline & Eryttrocyte $\left(10^{6} / \mathrm{mm}^{3}\right)$ & $2,95 \pm 0,76^{a}$ & $11,13 \pm 1,74^{c}$ & $11,13 \pm 1,74^{c}$ \\
\hline & Leucocyte $\left(10^{3} / \mathrm{mm}^{3}\right.$ & $10,13 \pm 1,42^{a}$ & $11,04 \pm 1,78^{c}$ & $11,04 \pm 1,78^{c}$ \\
\hline
\end{tabular}

Mean within column with different superscripts differ significantly $(\mathrm{P}<0.05)$

Related to reproduction, glucose is one of the key nutrients affecting fertility and cyclicity in farm animals which at lower level was postulated as the cause for decreased fertility rate as well as for non cyclicity. Therefore, Buffalo fed on C and B treatment had clear signs of estrus with a higher estrous frequency compared to group A. Low blood glucose such as in heifer buffalo only received rice straw (Group A) could potentially compromise a variety of essential metabolic processes in ovarian cells including the oocyte that depends on glucose for energy. The serum glucose is an important factor which modulates reproduction, and the lower glucose level is responsible for decreased fertility rate (Yadav et al., 1995).

Blood urea of buffalo that received diet B and $C$ at fasting conditions and two hours after eating was higher $(P<0.05)$ than buffalo fed diet A (control). This difference is due to differences in the composition and nutrient content of the feed. Group A buffalo were only fed rice straw which had low nitrogen content and was difficult to degrade compared to buffalo groups $B$ and $C$ which were supplemented with concentrates with high protein content and relatively easy to degrade. Although buffalo groups $B$ and $C$ were given the same concentrate, group $C$ buffalo had higher blood urea $(P<0.05)$. This is because buffalos in group $\mathrm{C}$ were given ammoniated rice straw which contains high NPN and is easily degraded (Khan et al., 2004). High level of blood urea in female buffaloes had negative effect on reproduction. Excess intake of $\mathrm{CP}$, related to increasing serum urea levels, might had led to delayed postpartum ovarian activity in Nili-Ravi buffaloes (Qureshi et al., 2002). Increasing of rumen un degradable protein (RUP) in the diets of buffalo decreased the fertility linearly in buffaloes fed iso-nitrogenous diets (Javaid et al., 2008). To avoid those reproduction problems, concentrate diets should have high fermentable carbohydrates to increase utilization of $\mathrm{NH}_{3}$ for microbial protein synthesis.

\section{Conclusions}

Heifer buffalo fed on ammoniated rice straw ensiled with cassava pulp and supplemented with concentrate ( $30 \%$ total dry matter intake) experienced an increased nutrient digestibility, rumen efficiency, production and reproductive performance compared to buffalo fed on rice straw only. The improved feed quality illustrates evident reproductive signs in cattle, such as heifer buffalo. 


\section{References}

Abdel-Latif, M.A., S. Emad, EL-Gohary, A.A. Gabr, A.F. El-Hawary, S. Ahmed, S.A. Ebrahim and M.M. Fathala. 2016. Impact of Supplementing Propylene Glycol and Calcium Propionate to Primiparous Buffalo Cows During the Late Gestation and Early Lactation Period on Reproductive Performance and Metabolic Parameters. AJVS. 51 (1): 114-

Abd El-Razek, E.M.M. and T.S. Allam. 2019. Some Biochemical Parameters and Hematological Picture in Cases of Smooth Inactive Ovaries in Buffalo-Cows. 60 (1): 83-92.

AOAC. 2019. Officials method of analysis, $21^{\text {st }} \mathrm{Ed}$. Association of Official Analytical Chemist, Washington, DC.

Bata, M. 2008. The effect of molasses on ammoniated straw by using urea on dry and organic matter digestibility as in vitro. Agripet: Vol (8) No. 2: 15-20.

Bush, R.D. 2009. Perinatal nutrition of the calf and its consequences for lifelong productivity. AsianAust. J. Anim. Sci. 22: 756-764.

Conte, G., R. Ciampolinib, M. Cassandroc, E. Lasagnad, L. Calamarie, U. Bernabuccif and F.A. Conte. 2018. Feeding and nutrition management of heat stressed dairy ruminants. Italian Journal of Animal Science. 17, 3: 604-620.

Dhali, A., R.K. Mehla, S.K. Sirohi, A. Mech and M. Karunakaran. 2006. Monitoring feeding adequacy in dairy cows using milk urea and milk protein contents under farm condition. Asian-Aust. J. Anim. Sci. 19:1742-1748.

Dinesh, T., R.K. Jain and R. Aich. 2016. effect of strategic nutrient supplementation on health, reproductive and productive status of buffaloes in the malwa region of madhya pradesh. Buffalo Bull., 35(2): 225 - 235.

Diwakar, P., C. Lailer, S. Chandra, N. Kumar, V. Purwar and D. Sahu. 2017. Effect of Different Feeding Ingredient under Field Condition on Reproductive Performance and its Validation in High Yielding Murrah Buffaloes at Farm Level. Int.J.Curr.Microbiol.App.Sci. 6(12): 2745-2748.

Davis, N.C. and E.L. Smith. 1958. Methods of Biochem. Analysis, Vol.2, $2^{\text {nd }}$ printing Ed. Gliok, Interscience Publisher, Ins., New York.

Gunun, P., M. Wanapat and N. Anantasook. 2013. Effects of Physical Form and Urea Treatment of Rice Straw on Rumen Fermentation, Microbial Protein Synthesis and utrient Digestibility in Dairy Steers. Asian Australas. J. Anim. Sci. 26:16891697.

Huntington, G.B. 1996. Starch utilization by ruminants: from basics to the bunk. J. Anim. Sci. 75:852-867.
Javaid, A., M. Nisa, M. Sarwar and M.A. Shahzad. 2008. Ruminal Characteristics, Blood pH, Blood Urea Nitrogen and Nitrogen Balance in Nili-ravi Buffalo (Bubalus bubalis) Bulls Fed Diets Containing Various Levels of Ruminally Degradable Protein. Asian-Aust. J. Anim. Sci. Vol. 21, No. 1: $51-58$.

Joch, M., L. Cermac, J. Haki, B. Hucko, D. Duskova and M. Marounek. 2016. In-vitro screening of essential oil activ compounds for manipulation of rumen fermentation and metahn mitigation. Asian Australas. J. Anim. Sci. 29.7: 952 - 959.

Khan, M.A., M. Sarwar, M. Nisa and M.S. Khan. 2004. Influence of enzose on feeding value of urea treated corncobs in lactating crossbred cows. Asian-Aust. J. Anim. Sci. 17:70-74.

Khan, M.A., Z. Iqbal, M. Sarwar, M. Nisa, M.S. Khan, W.S. Lee, H.J. Lee and H.S. Kim. 2005. Urea Treated Corncobs Ensiled with or without Additives for Buffaloes: Ruminal Characteristics, Digestibility and Nitrogen Metabolism.

Khan, M.A., M. Sarwar, M. Nisa, M.S. Khan, S.A. Bhatti, Z. Iqbal, W.S. Lee, H.J. Lee, H.S. Kim and K.S. Ki. 2006. Feeding value of urea treated wheat straw ensiled with or without acidified molasses in Nili-Ravi Buffloes. Asian-Aust. J. Anim. Sci. 19:645 - 650.

Kholif, A.E., H.M. Khattab, El Shewy, A.A. Salem, A.Z.M. Kholif, A.M. El-Sayed, M.M. Gado and M.D. Mariezcurrena. 2014. Nutrient digestibility, ruminal fermentation activities, serum parameters and milk production and composition of lacting goats fed diets containing rice straw treated with Pleurotus ostreatus. Asian-Aust. J. Anim. Sci. 27: 357-364.

Krause, M., K.A. Beauchemin, L.M. Rode, B.I. Farr and P. Norgaard. 1998. Fibrolytic enzyme treatment of barley grain and source of forage in high-grain diets to growing cattle. J. Anim. Sci. 76:2912 - 2920.

Krooman, R.P., J.H. Meyer and W.J. Stielau. 1967. Steam Destillation of Volatile Fatty Acid in Rumen Ingesta. J. Dairy. Sci. 50:73

Kumar, V.S., R.P. Kumar, C.H. Harikrishna and M.S. Rani. 2018. Effect of heat stress on production and reproduction performance of buffaloes-A review. The Pharma Innovation Journal. 7(4): 1076-1079.

Liu, J.J., X.P. Liu, J.W. Ren, H.Y. Zhao, X.F. Yuan, X.F. Wang, Z.M.S. Abdelfattah and Z.J. Cui. 2015. The effect of fermentation and adsorption using lactic acid bacteria broth on the feed quality of rice straw. Journal of Integrative Agriculture. 14(3): $503-513$.

Lizarazo, A.C., G.D. Mandoza, J. Ku, L.M. Melgoza and M. Crosby. 2014. Effect of slow- release urea and molasses on ruminant metabolism of 
lamb fed with low-quality tropical forage. Small Ruminant Research. 116: 28 -31

McGuire, D.L., D.W. Bohner, C.S. Schauer, S.J. Falck and R.F. Coke. 2013. Daily and alternate day supplementation of urea and soybean meal to ruminants consuming low-quality cool-season forage: I- Effects on efficiency of nitrogen use and nutrient digestion. Livestock Science. 155: $205-2013$

Makkar, H.P.S., O.P. Sharma, R.K. Darwa and S.S. Negi. 1982. Simple Determination of Microbial Protein in Rumen Liquar. J. Dairy. Sci. 65: 2170 2173

Maeng, W.J., H. Park and H.J. Kim. 2003. The role of carbohydrate supplementation in microbial protein synthesis in the rumen. In: Rumen Microbes and Digestive Physiology in Ruminants. Eds: by Onedera, R. H. Itabashi, K. Ushida, H. Yano and Y. Sasaki. Japan Scientific Societies Press, Tokyo.

Nguyen, T.H., Q. Bui, N. Tuan, N. Xuan, T.B.T. Nguyen and T.T.L. Nguyen. 2017. Effect of using fungal treated rice straw in sheep diet on nutrients digestibility and microbial protein synthesis. Asian-Aust. J. Anim. Sci. 13(1):1-7.

Nisa, M., M. Sarwar and M.A. Khan. 2004. Nutritive value of urea treated wheat straw ensiled with or without corn steep liquor for lactating Nili-ravi Buffaloes. Asian-Aust. J. Anim. Sci. Vol 17, 6:825 - 829.

Oladosu, Y., Y. Mohd, Rafii, N. Abdullah, U. Magaji, G. Hussin, A. Ramli and G.M. Oladosu. 2016. Fermentation Quality and Additives: A Case of Rice Straw Silage. BioMed Research International. BioMed Research International. Article ID 7985167, 14 pages.

Orden, E.A., K. Yamaki, T. Ichinohe and T. Fujihara. 2000. Feeding value of ammoniated rice straw supplemented with rice bran in sheep: II. In Situ rumen degradation of untreated and ammonia treated rice straw. Asian-Aus. J. Anim. Sci. 13: 906- 912 .

Phogat, J.B., K.P. Anand and S. Inderjeet. 2016. seasonality in buffaloes reproduction sing International Journal of Plant. Anim. Environ. Sci. Vol. 6 (2):46- 54.

Qureshi, M.S., S. Khan and N. Ahmad. 2007. Pregnancy depresses milk yield in dairy buffaloes. Italian J. Anim. Sci. 6: (Suppl. 2):1290-1293.

Roy, K.S. and B.S. Prakash. 2009. Plasma progesterone, oestradiol-17 $\beta$ and total oestrogen profiles in relation to oestrous behaviour during induced ovulation in Murrah buffalo heifers. J. Anim. Physiol. Anim. Nutr. 93:486-495.

Russel, J.B. J.D. O'Comor, D.G. Fox, P.J. Van Soest and C.J. Sniffen. 1992. A net carbohydrate and protein system for evaluation cattle diets: I.
Ruminal fermentation. J. Anim. Sci. 70: 3551 3561.

Safari, J.G., D.E. Mushi, L.A. Mtenga, G.C. Kifaro and L.O. Eik. 2011. Growth, carcass yield and meat quality attributes of Red Maasai sheep fed wheat straw-based diets. Trop. Anim. Health Prod. 43:89-97.

Sahoo, A., A.V. Elangovan, U.R. Mehra and U.B. Singh. 2004. Catalytic supplementation of ureamolasses on nutritional performance of male buffalo (Bubalus bubalis) calves. Asian- Aust. J. Anim. Sci. 17:621-628.

S.A.S. 1998. User's Guide: Statistic, Version 5. Edition. SAS. Inst Cary, NC, USA.

Sarwar, M., M.A. Khan and M. Nisa. 2003. Nitrogen retention and chemical composition of urea treated wheat straw ensiled with organic acids or fermentable carbohydrates. Asian- Aust. J. Anim. Sci. 16:1583 - 1590 .

Sarwar, M., M.A. Khan, M. Nisa, S.A. Bhatti and M.A. Shahzad Sarwar. 2009. Nutritional Management for Buffalo Production. Asian-Aust. J. Anim. Sci. 22(7):1060-1068.

Sarnklong, C., J.W. Cone, W. Pellikaan and W.H. Hendriks. 2010 Utilization of Rice Straw and Different Treatments to Improve Its Feed Value for Ruminants: A Review. Asian-Aust. J. Anim. Sci. 23(5):680-692 Asian-Aust. J. Anim. Sci. 23(5):680692.

Scaramuzzi, R.J., B.K. Campbell, J.A. Downing, N.R. Kendall, M. Khalid, M. Munoz-Gutiérrez and A. Somchit. 2006. A review of the effects of supplementary nutrition in the ewe on the concentrations of reproductive and metabolic hormones and the mechanisms that regulate folliculogenesis and ovulation rate. Reproduction, Nutrition, and Development 46, 339-354.

Singh, U.B. Mehra and R. Usha. 1990. Utilization of ammoniated wheat straw given in feed blocks and supplemented with varying quantities of fish meal and oil extracted rice bran.Anim. Feed Sci. Technol. 29:129-134.

Syapura, M. Bata and W.S. Pratama. 2013. Improving of rice straw quality and its effect on ability nutrient digestibility and rumen metabolism products of buffalo in-vitro with feces as inoculum source. Agripet: Vol (13) No. 2 : 59-67.

Steel, R.G.D. and J.H. Torrie. 1980. Principals and procedures of statistics-A biometrical approach. 2nd ed. McGrawhill Book Company, New York

Sweeny, J.P., A.V. Surridge, P.S. Humphry, H. Pugh and K. Mamo. 2014. Benefits of different urea supplementation methods on the production performances of Merino sheep. Viterinary Journal. 200: $398-403$ 
Tilley, J.M.A. and R.A. Terry. 1963. A two-stage technique for the in vitro digestion of forage crops Current Contents. J.British Grass.Soc. 18:104-111.

Van Soest, P.J. 2006. Rice straw, the role of silica and treatments to improve quality. Anim Feed Sci. and Technol. 130(3-4): 137-171, 2006.

Wynn, P.C., H.M. Warriach, A. Morgan, D.M. McGill, S. Hanif, M. Sarwar, A. Iqbal, P.A. Sheehy and Warriach H.M., D.M. McGill, R.D. Bush and P.J. Wynn. 2015. A Review of recent developments in Buffalo Reproduction-A Review. Asian Australas. J. Anim. Sci. 28:451-455.

Wanapat, M., K. Phesatcha and S. Kang. 2016. Rumen adaptation of swamp buffaloes (Bubalus bubalis) by high level urea supplementation when fed on rice straw-based diet. Trop Anim Health Prod. 48 (4): 1135 -1140
West, J.W., B.G. Mullinix and J.K. Bernard. 2003. Effects of hot, humid weather on milk temperature, dry matter intake, and milk yield of lactating dairy cows. J Dairy Sci. 86:232-242

Wyman, C.E., S.R. Decker, M.E. Himmel, J.W. Brady, C.E. Skopec and L. Viikari. 2005. Hydrolysis of cellulose and hemicellulose," in Polysaccharides: Structural Diversity and Functional Versatility, vol. (1) :1023-1062

Yadav, N.K., J.S Lohan, B. Singh and D. Chand. 1995. Studies on some serum constituents in anoestrous buffaloes. Indian J Anim. 29(1):85-8.

Zhang, Xi, M. Wang, R. Wang, Z. Ma, D. Long, H. Mao, J. Wen, L.A. Bernard, K.A. Beauchemin and Z. Tan. 2018. Urea plus nitrate pretreatment of rice and wheat straws enhances degradation and reduces methane production in in vitro ruminal culture. J. Sci. Food. Agric. 98: 5205 -5211. 